Meta

Journal des traducteurs

Translators' Journal

\title{
Intensive Summer Training in Simultaneous Interpretation at the University of Delaware
}

\section{Nancy Schweda-Nicholson}

Volume 31, numéro 4, décembre 1986

URI : https://id.erudit.org/iderudit/004076ar

DOI : https://doi.org/10.7202/004076ar

Aller au sommaire du numéro

Éditeur(s)

Les Presses de l'Université de Montréal

ISSN

0026-0452 (imprimé)

1492-1421 (numérique)

Découvrir la revue

Citer cette note

Schweda-Nicholson, N. (1986). Intensive Summer Training in Simultaneous

Interpretation at the University of Delaware. Meta, 31(4), 457-457.

https://doi.org/10.7202/004076ar d'utilisation que vous pouvez consulter en ligne. 
the skills of simultaneous interpretation. The intensive program, which was held from July 21-August 9,1985 , brought together Society translators from Argentina, Brazil, Columbia, France, Germany, Mexico, Puerto Rico, and the United States. The specialized intensive training course was the brainchild of Robert Conrads, Assistant Manager of the Christian Science Publishing Society's Department of Translations. Conrads, who first approached Delaware Interpretation Program with his idea in January, 1985, tested the prospective students rigorously before they were chosen to participate. He used the University of Delaware's Interpretation Program Screening Examination to aid him in the selection process.

The intensive summer training was a first for the University's Interpretation Program, which was established in 1979. The regular Certificate Program, which consists of four three-credit courses and whose working languages are English, Spanish and French, is offered during the Fall and Spring semesters only. This educational endeavor was also a first for the Society; up until now, it has not had its own simultaneous interpreters. Karl Kummer, Manager of the Society's Department of Translations, led the group of twelve, which was divided by working languages into three small groups (English/French, English/German, and English/Spanish).

Earlier this year, Conrads worked with Robert J. Di Pietro, Chairman of the Department of Languages and Literature and Director, Program in Linguistics; Richard Fischer, Associate Director for Statewide Programming of the University's Continuing Education Department; and Johanna den Thuinder, the Director of the intensive summer program, to plan the schedule, make classroom and housing arrangements, and select appropriate course material.

During the three-week period, the translators attended classes Monday through Saturday for six hours per day. The use of the University's state-ofthe-art wireless simultaneous interpretation equipment and booths contributed much to their training experience.

After completing the intensive program, the new interpreters were immediately put to the test. From August 16-18, they worked at a meeting of Christian Science College Organizations in Boston, which brought together 3000 students and advisors from all over the world. The Society will employ its new interpreters frequently for a variety of assignments. For example, later this year, they will work at a series of workshops to be held in France and Germany. As well, the interpreters will also provide simultaneous interpretation services at the Annual Meeting of the First Church of Christ, Scientist in Boston on a regular basis.

The University of Delaware Interpretation Program received a $44000 \$$ contract from the ChrisNANCY SCHWEDA-NICHOLSON University of Delaware, USA 